\title{
La herencia criolla en la cultura actual. Lecturas coloniales en el ensayo moderno guatemalteco
}

\author{
Ana Lorena Carrillo \\ Universidad Autónoma de Puebla, México \\ lorencarr@yahoo.com
}

\begin{abstract}
Resumen
El presente artículo se propone analizar el papel de algunas obras literarias en la recreación histórica y cultural de Guatemala. Busca mostrar algunos vínculos intertextuales entre las mismas, así como evidenciar el peso de las tradiciones heredadas desde la dominación criolla colonial en la recreación histórica y literaria contemporánea y en sus formas de representación. El trabajo se basa en la relación entre dos de los ensayos más importantes de la segunda mitad del siglo XX, escritos desde una perspectiva crítica de izquierda: Guatemala, las líneas de su mano, de Luis Cardoza y Aragón y La patria del criollo, de Severo Martínez Peláez, con las dos obras más importantes del pensamiento criollo y la literatura colonial del país: la Recordación florida, de Francisco Antonio de Fuentes y Guzmán y la Rusticatio mexicana, de Rafael Landívar, representativas del pensamiento de las élites criollas.

Palabras clave: GUATEMALA, LITERATURA COLONIAL, ENSAYO, SIGLO XX.
\end{abstract}

\begin{abstract}
This article analyzes the role of certain literary works in the historic and cultural recreation of Guatemala. It seeks to show some of the intertextual linkages between them, as well as evidencing the weight of traditions bequeathed by creole domination during colonial times onto contemporary historical and literary creation, as well as their forms of representation. The article is based upon the relationship between two of the most important essays of the second half of the $20^{\text {th }}$ century written from a left wing critical stance; Guatemala, las lineas de su mano, by Luis Cardoza y Aragón and La patria del criollo, by Severo Martínez Peláez, and the two most important texts of creole thought and colonial literature: the Recordación florida, by Francisco Antonio de Fuentes y Guzmán and the Rusticatio mexicana, by Rafael Landívar.
\end{abstract}

Key words: GUATEMALA, COLONIAL LITERATURE, ESSAY, $20^{\mathrm{TH}}$ CENTURY. 
En 1955 y 1970, respectivamente, salieron a la luz las obras de Luis Cardoza y Aragón Guatemala, las líneas de su mano ${ }^{1}$, y de Severo Martínez, La patria del criollo $^{2}$, que más tarde han sido consideradas como las más importantes dentro del género del ensayo nacional moderno en el país. Ambos autores y sus obras son buenos ejemplos para ilustrar el momento histórico, intelectual y literario de Guatemala en la segunda mitad del siglo XX y se inscriben en el esfuerzo por dotar, desde la tradición culta y erudita, de referentes históricos y culturales

${ }^{1}$ Luis Cardoza y Aragón, Guatemala, las líneas de su mano (Guatemala: México: Editorial Universitaria, Universidad de San Carlos, 1997). La obra es una síntesis histórica general y a la vez un retrato particularizado de la sociedad y la cultura guatemalteca desde el período prehispánico hasta 1954. Su autor la escribió en el contexto del recién consumado derrocamiento del gobierno del coronel Jacobo Arbenz, como una interpretación general del país dirigida a guatemaltecos y extranjeros urgidos de comprender individual y socialmente el acontecimiento y darle sentido histórico. Ese año, una intervención norteamericana, en alianza con los terratenientes locales, derrocó al presidente Arbenz y con ello canceló el proceso iniciado en 1944, conocido como la Revolución de Octubre, que se proponía un proyecto democrático-nacionalista encabezado por las clases medias. Este hecho marcó en definitiva la historia política del país hasta la actualidad. Cardoza y Aragón ocupó cargos diplomáticos en los gobiernos revolucionarios y encabezó importantes iniciativas culturales. Su prestigio intelectual como escritor y poeta era entonces ya reconocido en México, donde vivió antes y después de la experiencia guatemalteca de 1944-1954 y en otros países. Fue delegado a la Novena Conferencia Panamericana (Colombia, 1947) y testigo del Bogotazo. El episodio figura en su monumental memoria $\mathrm{El}$ Río, novelas de caballería, que es, a su vez, una mirada autobiográfica del siglo $\mathrm{XX}$ (México: Fondo de Cultura Económica, 1986). Murió en México, en 1992.

2 Severo Martínez Peláez, La patria del criollo (Guatemala: Editorial Universitaria, Universidad de San Carlos, 1970; reimpresión, México: Universidad Autónoma de Puebla, 1981). Los números de página citados corresponden a ella. Se trata de la más importante obra de la historiografía colonial guatemalteca escrita en el país hasta entonces. El subtítulo "Ensayo de interpretación de la realidad colonial guatemalteca" no deja dudas sobre su filiación y objeto. En ella, su autor realiza simultáneamente historia social, de las mentalidades y de la cultura a través de la lectura interpretativa de la obra que le sirvió de guía: la Recordación florida, de Antonio de Fuentes y Guzmán, crónica o "relación historial" del siglo XVII, que informa sobre la historia y las características económicas y geográficas del país y expresa, además, el pensamiento de los encomenderos criollos. El análisis de Martínez revela la perduración de la mentalidad de aquella élite en la de la contemporánea oligarquía terrateniente y denuncia el carácter económico-segregacionista de su proyecto, inspirado en las premisas ideológicas de clase construidas en el período colonial. Esbozando dicho régimen como "feudal", en la proletarización de los indígenas guatemaltecos, iniciada con el fin del trabajo forzado en la legislación de los gobiernos revolucionarios de 1944-1954, establece la clave para sus posibilidades ciudadanas y la definición de un proyecto alternativo. Martínez escribió y publicó la obra en un contexto de auge de revueltas populares y del movimiento revolucionario armado de entonces, que hacía suyas las reivindicaciones de los pueblos indígenas. Fue profesor universitario y exiliado en México, tanto en 1954 como en 1979, donde ocupó cargos académicos en la Universidad Autónoma de Puebla, ciudad en la que murió en 1998. 
nacionales, a un país desgarrado por crisis políticas y fracturas sociales y étnicas ${ }^{3}$. La huella de ambos ensayos en la política, la literatura y la historiografía del período en cuestión es innegable, como lo son igualmente su perdurable influencia, largo ciclo vital y lograda configuración artística. De hecho, sus obras fueron detonantes de una renovación en las formas y en las perspectivas epistemológicas dentro del contexto nacional y, eventualmente, latinoamericano ${ }^{4}$, además de que exploraron por vías originales, desde el ensayo histórico, el camino de las apropiaciones "barrocas" o no que, junto a otras tradiciones, las letras latinoamericanas habían venido realizado en distintos momentos y con distintos fines. Apropiaciones múltiples y contradictorias, no solo coloniales ni solo barrocas, que en última instancia refieren a un concepto de historia como tensión dialógica entre tiempos y espacios yuxtapuestos y entreverados y como recreación de diversas tradiciones culturales No obstante, la aparente y celebrada cancelación de la historia y el descrédito de los proyectos políticos nacionales, democráticos y populares en que ambos autores se hallaban comprometidos, así como la reactivación en América Latina de una cierta crítica cultural y literaria a la "modernidad" y a sus "grandes relatos", hacen correr el riesgo de que se desestimen y paulatinamente dejen de reconocerse y actualizarse obras que como estas, recusan un concepto de historia basado en centrífugas y fragmentos y representan en cambio eslabones significativos de la historia literaria, cultural y

\footnotetext{
${ }^{3}$ En la misma orientación, se inscriben las realizaciones previas de Miguel Ángel Asturias y Raúl Leiva, desde la novela y la poesía, respectivamente, así como de Mario Monteforte Toledo, también novelista. Marc Zimmerman, Guatemala, voces desde el silencio. Un collage épico (Guatemala: Palo de Hormigo-Óscar de León Palacios, 1993), 16.

${ }^{4}$ Véanse, por ejemplo, las reflexiones del historiador costarricense Iván Molina en torno a las valoraciones "latinoamericana" y "anglosajona" que caracterizan la recepción de la obra de Martínez en los años setenta en los historiadores latinoamericanistas de los años setenta que, desde distintas posturas, dieron muestras del efecto que la propuesta metodológica e ideológica de Martínez produjo en el medio. Por otra parte, la obra representa una renovación también por cuanto abre para la historiografía colonial hecha desde Centroamérica el proceso de incorporación de dicha disciplina al boyante desarrollo de las "ciencias sociales" latinoamericanas, encabezado entonces por la economía y la sociología. Iván Molina, "La patria del criollo, tres décadas después", en La patria del criollo tres décadas después, Óscar Peláez Almengor (Guatemala: Editorial Universitaria, Universidad de San Carlos, 2000), 199-221. En cuanto a la obra de Cardoza, su renovación, previa a la que también realiza Martínez y desde caminos propios, del "ensayo de interpretación" de Mariátegui se combina con la propuesta de un concepto de historia que, como el de Octavio Paz, en El laberinto de la soledad, la concibe como una sabiduría, más que como un saber que realiza un acercamiento a la experiencia histórica desde la poesía. Véanse, entre otros, Lionel Méndez D’Avila, Cardoza y Aragón, obra y compromiso (modelo con un paraíso, un infierno y un río) (Guatemala: Editorial Universitaria, Universidad de San Carlos, 1999), y Lucrecia Méndez de Penedo, Memorie Contracorrente, El Río, novelas de Caballería de Luis Cardoza y Aragón (Roma: Consiglio Nazionale Delle Ricerche-Bulzoni Editore, 2001).
} 
política latinoamericana portadores de la complejidad y contradicciones con que esta se construye. Mantener su vigencia no podría ser resultado sino de una revisión y lectura actualizada que trascienda la dicotomía del elogio o la denostación y que acepte las paradojas que las conforman. Una lectura que, sin eludir la crítica, sitúe a las obras y sus autores en un horizonte epistemológico del que aún somos deudores y desde el cual su discurso continúa planteándonos interrogantes.

Los siguientes comentarios sobre Luis Cardoza y Aragón y Severo Martínez Peláez, venidos de jóvenes críticos y narradores guatemaltecos, sirven bien para dar una idea de la perspectiva desde la que hoy se realizan lecturas de dichas obras. Lecturas en que las actuales nociones del saber como "información" y los "lugares" sociales como "centros" y "márgenes" informan la mirada crítica que desde hoy se hace a la segunda mitad del siglo XX latinoamericano y a sus intelectuales:

Bajo el fluir de la prosa, [de Cardoza] el sedimento de las ideas de un encomendero venido a menos 5 .

El surrealismo, que siempre obscurece el producto le salvó de la cursilería a Cardoza, pues Cardoza era un hombre muy cursi ${ }^{6}$.

Tenemos que contribuir a que cada día los indígenas se ocupen más ellos mismos de sus cosas" No es paternalista eso? no es Severo Martínez?

Cardoza y Martínez, encomenderos venidos a menos, paternalistas y cursis. Algo hay de cierto. En muchas de las páginas de ambos autores surgen imágenes, ideas y palabras con sensibilidad propia del imaginario fastuoso y exagerado de la aristocracia criolla, pero ir más allá de los meros adjetivos y adentrarse en los textos supone enfrentarse a un problema de gran complejidad: la contradictoria presencia de formas narrativas de la cultura criolla y su raigambre colonial en Guatemala, las líneas de su mano y La patria del criollo. Contradictoria en tanto que ambas son piezas fundadoras de la construcción social de las ideas modernas de patria y nación en el país, ancladas en tradiciones intelectuales y políticas que han buscado distanciarse de la mentalidad y cultura oligárquica. En los resultados que arroja la revisión de la lectura que sus autores hicieron de textos coloniales,

5 Ronald Flores, "Cardoza extravagante", Cultura de Guatemala, edición Homenaje Centenario Luis Cardoza y Aragón, Programa Patrimonio Cultural e Identidad NUFU/URL (Guatemala), 3 (septiembre-diciembre 2001): 211-213.

${ }^{6}$ Maurice Echeverría, "Cardoza: instantáneas cibernéticas", en Luis Cardoza y Aragón. Centenario 1901-2001 (Guatemala: Fondo de Cultura Económica de Guatemala, 2001), 5964

${ }^{7}$ Ibídem, 60. Resaltados de la autora. 
que a su vez fundaron en su momento la idea primaria de patria criolla, se encuentran claves que no solo explican la persistencia de remanentes de la cultura criolla en los textos de Cardoza y Martínez, sino proponen una reflexión sobre las implicaciones de la misma en obras modernas que, aunque parten de una visión del mundo definida por su filiación con los sectores populares y desde su perspectiva ideológica, lo hacen a partir de un discurso que -en consonancia con el proceso histórico- no se desembaraza fácil ni plenamente de sus anclajes en el universo ideológico de la clase dominante.

El encuentro con esta señal de la persistencia de la ideología señorial en Guatemala y de las grandes contradicciones con que se manifiesta en la producción literaria e historiográfica contemporánea emergió de una lectura a contrapelo de las obras de Cardoza y Martínez centrada en su doble estatuto de discurso histórico-literario, su dimensión estética, sus imágenes, representaciones y símbolos, haciendo uso de ciertos conceptos de la crítica literaria y la hermenéutica histórica ${ }^{8}$.

En un trabajo anterior ${ }^{9}$ presenté algunos desarrollos previos de la propuesta que aquí expongo, relativos a la obra de Severo Martínez. Ahí proponía que algunos tópicos, como los del terremoto y la plaza que evoca en el párrafo con que inicia su obra, corresponden no solamente al "estilo" personal del autor, sino a uno propio de la época colonial, a una específica forma de elaboración del discurso historiográfico característico de los eruditos e intelectuales de la "patria criolla" del siglo XVII, y presentaba como ilustración las similitudes existentes entre ese fragmento de la obra contemporánea de Martínez y uno de la obra colonial mexicana de Carlos de Sigüenza y Góngora ${ }^{10}$. También señalaba cómo la representación del espacio como panoramas o paisajes en la Recordación florida de Antonio de Fuentes y Guzmán, el cronista colonial con quien dialoga la obra de Martínez, contiene ricos significados ideológicos que encuentran ecos en ella ${ }^{11}$,

\footnotetext{
${ }^{8}$ Este proyecto se realizó en mi trabajo "Narrativa e historia nacional en Guatemala en la segunda mitad del siglo XX", cuya publicación como libro preparo actualmente. Los conceptos teóricos implícitos en este trabajo provienen de las variadas perspectivas que desde la historiografía, la teoría y la crítica literaria y cultural analizan las relaciones entre el campo de la historia y el de la literatura.

${ }^{9}$ Ana Lorena Carrillo, "Crónica, discurso criollo y relato historiográfico en La patria del criollo de Severo Martínez Peláez”, Mesoamérica (Guatemala), 44 (diciembre 2002): 118133.

${ }^{10}$ El fragmento de Sigüenza y Góngora pertenece a la carta que este le escribió al almirante Andrés de Pez, intitulada Alboroto y motín de los indios de México el 8 de junio de 1692, que aparece citada en el trabajo de Leonard Irving "Un sabio barroco", en Lectura crítica de la literatura americana. Inventarios, invenciones y revisiones, selección, prólogo y notas Saúl Sosnowski (Caracas, Venezuela: Biblioteca Ayacucho, 1996), 1: 653-663.

11 De hecho, los temas de inestabilidad y muchedumbre en la plaza, así como la introducción de la perspectiva como noción epistemológica, son características de la literatura barroca que en Europa se relacionaban con el malestar generado por la
} 
sumándose el discurso criollo en esta última a otros discursos sociales que conviven en el texto, representándose así la complejidad social de la que el contenido de la obra da cuenta. También se elabora la idea de que el análisis histórico de la crónica de Fuentes y Guzmán que realiza Martínez fue al mismo tiempo un intuitivo análisis literario que, infortunadamente, no desarrolló a cabalidad. No obstante, alrededor del tema del barroco o del "barroquismo" en dicha crónica, el historiador expresa un elaborado concepto de la forma artística de la obra y de sus significados ideológicos, además de que abre la puerta para que dicho concepto se aplique a su propia forma artística, evocando, adaptándola a su propio tiempo, la del cronista colonial ${ }^{12}$. La complejidad del acercamiento de Martínez a la obra y la personalidad del cronista criollo se expresa en el doble registro que perdura desde el inicio hasta el final de La patria del criollo: por un lado, admiración en el uso de los adjetivos dedicados a su obra: "enorme", "monumental", "inmenso"; por otro, distanciamiento en el uso de la tercera persona, en el discurso parodiado ${ }^{13}$, en la polémica axiológica. Al final, en el momento de redondear el concepto total de la arquitectura de su propia obra, Martínez crea un recurso de conciliación a partir de la figuración de un lugar de coincidencia: el de la palabra y el discurso del saber:

Las últimas palabras de este libro han de aludir al personaje que nos salió al encuentro en las primeras páginas y nos acompañó por los caminos del Reino de Guatemala en el siglo XVII: el cronista criollo, cuya obra estupenda, llena de pasión y escrita para defender y afirmar los derechos de su clase en una trama de contradicciones sociales, nos permitió penetrar en esa trama y encontrar claves decisivas para la comprensión de nuestro pasado ${ }^{14}$.

Es en el "camino" de la palabra erudita que es posible el "encuentro". Es en el espacio del "libro" y de la "trama" del Reino de Guatemala del siglo XVII devueltos así a su condición de mera recreación del lenguaje- que ambos coinciden. Un espacio no inocente ni llano, por cierto, sino intrincado, lleno de

experiencia vital de la crisis generalizada del siglo XVII. Véase, José Antonio Maravall, $L a$ cultura del Barroco: análisis de una estructura histórica (Barcelona: Ariel, 1996), 66.

${ }^{12}$ El tema del barroco en la literatura colonial y sus huellas en la contemporánea es de gran complejidad. En el estudio que venimos citando y en este mismo, solamente se recupera su sentido histórico y político, que rebasa ampliamente su caracterización dentro de los problemas de "estilo". Véase, entre otros, Mabel Moraña, "Para una relectura del Barroco hispanoamericano: problemas críticos e historiográficos", en Sosnowski, Lectura crítica, 653-663.

${ }^{13}$ Viene al caso la interpretación de la parodia como homenaje y no como desacralización que ofrece Claudio Magris en Utopía y desencanto. Historias, esperanzas e ilusiones de la modernidad (Barcelona: Anagrama, 2001), 51-54.

${ }^{14}$ Martínez, La patria del criollo, 636. Resaltados de la autora. 
pasión, contradicciones y laberintos, como la poética barroca misma. Pero también un espacio de poder. Por lo demás, el "encuentro" y el "camino" son índices que pertenecen a definiciones temporales y espaciales profundas: el encuentro en el camino es un motivo literario que apunta justamente a la coincidencia en el mismo tiempo y en el mismo lugar ${ }^{15}$. ¿Existe una mejor forma de ilustrar, mediante la organización artística del lenguaje y las imágenes del texto lo que el propio autor argumenta en su discurso? La "nación" ha sido concebida desde la ideología criolla y es esta la que signa aquel espacio de encuentro, aquella trama densa y cerrada como un cofre colonial a la que el cronista "permite" el paso ${ }^{16}$. Se trata del campo común a ambos del saber jerarquizado que, sin embargo, y en tensa contradicción, se estructura, en la versión de Martínez, en torno a una nueva pasión: convertir a los indios en sujetos de la historia.

El análisis crítico de las obras de Martínez y Cardoza se sustenta en los desarrollos teóricos elaborados en torno al tema de la relación de complementariedad y requerimiento mutuo entre los discursos literario e histórico, la cual ha sido eje de la discusión en una importante corriente del pensamiento contemporáneo que se expresa en la hermenéutica, la filosofía del lenguaje, la teoría literaria y la teoría de la historia ${ }^{17}$. Entre los más importantes debates involucrados en dichas elaboraciones está el del conocimiento. Historia y literatura dan cuenta de espacios, tiempos y sujetos y proponen siempre relaciones dialógicas con "otros". Sus referentes ficcionales o reales se realizan en el discurso de un modo siempre referido a contrapartes con que dialogan conflictivamente. Es en esa tensión dialógica que, en cada presente, la historia y la literatura apelan, discuten, retoman $\mathrm{y}$ reelaboran las formas, los géneros del discurso y el pensamiento que les ha antecedido, recreando así la cultura y el conocimiento. Una concepción de historia y de literatura que recusa la capacidad de ambas de dar cuenta de espacios, tiempos y sujetos concretos, da por concluida su capacidad de dar sentido y significación al tiempo humano y diluye estas nociones y también la posibilidad del conocimiento mismo $^{18}$. Sin constituir un campo definido y sin rutas certeras ya preestablecidas,

\footnotetext{
${ }^{15}$ Mijaíl Bajtin, "Las formas del tiempo y el cronotopo en la novela. Ensayos de poética histórica", en Teoría y estética de la novela, trads. Helena Kriúkova y Vicente Cazcarra (Madrid: Altea-Taurus-Alfaguara, 1989), 250-251.

${ }^{16}$ Se alude aquí al importante motivo de la llave colonial que Martínez propuso para ilustrar la portada de sucesivas ediciones de su obra. La patria del criollo pretendía "abrir" el conocimiento de la realidad histórica y social de Guatemala. Del mismo modo, la Recordación florida y su autor "permitían" el acceso y daban las "claves" del conocimiento de su mundo.

${ }^{17}$ Los autores más conocidos por obras inscritas en esta corriente son Paul Ricouer, Mijaíl Bajtín, Jaques Ranciere. También Paul Veyne, Hayden White y Michel de Certau.

18 "Introducción" en Historia y literatura, comp. Francoise Perus (México: Instituto Mora, 1994), 7-28. Véase también de la misma autora "Aportes de la crítica literaria a la cultura
} 
aquí se abordan estas obras desde una perspectiva interdisciplinaria que contempla lo que está en juego en dicho debate. El acercamiento a los textos como "lugares" de encuentro de diversas tradiciones, temporalidades y espacios, así como de sujetos siempre en diálogo y redefinición, es lo que permite proponer la doble lectura que aquí se ofrece de ellos: la que hicieron las obras mismas y sus autores de los textos coloniales y la que desde el presente intenta desentrañar sus significados.

La obra de Luis Cardoza y Aragón, publicada quince años antes que la de Martínez, tiene también dos importantes referencias a textos coloniales: la Historia Verdadera de la conquista de la Nueva España, de Bernal Díaz del Castillo ${ }^{19}$ y la Rusticatio mexicana ${ }^{20}$, de Rafael Landívar, a los que impone su propio régimen de lectura. Sin embargo, no son tratados del mismo modo que en el texto de Martínez. Curiosamente, el autor desdeña la Recordación florida como obra importante en la

latinoamericana", Latinoamérica. Anuario de Estudios Latinoamericanos (México), 35 (2002): 81-136.

${ }^{19}$ Crónica testimonial que Bernal Díaz del Castillo (Medina del Campo, 1495 o 1496), soldado en la campaña de Hernán Cortés, escribe a lo largo de treinta años para refutar las versiones de Francisco López de Gómara acerca de la conquista. La obra se publicó tardíamente, hacia 1632. Aunque alude básicamente a la conquista de México, el autor, que fue regidor de Guatemala, la escribió ahí, en la ciudad de Santiago de los Caballeros, hoy Antigua Guatemala - ciudad natal de Luis Cardoza y Aragón, a la que dedica largas páginas en su obra, aquí comentada-, donde finalmente murió. Su obra, además de que rompe con el modelo historiográfico de las crónicas anteriores, asentado en criterios de autoridad, crea un modelo literario. Su escritura es memorialista, subjetiva y parcial, pero en su acto "democratizador" de la historia, relata, a partir de fuentes, enraizadas en la literatura popular y la tradición oral, el otro lado de la Conquista. Bernal Díaz del Castillo, Historia verdadera de la conquista de la Nueva España, introd. y notas Joaquín Ramírez Cabañas, (México: Porrúa, 1960).”Introducción”, Crónicas de Indias, Antología, ed. Mercedes Serna, (Madrid: Cátedra, 2000):15-105.

${ }^{20}$ Obra poética de la escuela neoclásica escrita en latín por el jesuita Rafael Landívar, nacido en Santiago de los Caballeros (Antigua Guatemala) en 1731. La obra se publicó en Módena y Bolonia, Italia, en 1781 y 1782, donde el autor vivió el exilio desde la expulsión de los jesuitas y donde muere en 1793. Se trata de un canto al hombre, naturaleza, costumbres y fenómenos raros de las tierras americanas, especialmente, de México y Guatemala. Henríquez Ureña lo considera iniciador del paisaje y el primero que rompe con las convenciones del Renacimiento y descubre los rasgos característicos de la naturaleza en el Nuevo Mundo. Su perspectiva es la de un intelectual de la élite criolla que ya no mira al pasado de la conquista ni al vigente poder metropolitano, sino a la afirmación de la "patria criolla" y de "lo criollo" como ruptura, híbrida, respecto a las amarras con "la madre patria". Rafael Landívar, Rusticatio mexicana, ed. crítica bilingüe Faustino Chamorro G. (Guatemala: Universidad Rafael Landívar, 2001). Pedro Henríquez Ureña, Las corrientes literarias en la América Hispánica (La Habana: Instituto Cubano del Libro, s. f.), 88. "Prólogo", en Ruptura de la conciencia hispanoamericana, ed. José Anadón (Madrid: Fondo de Cultura Económica, 1993), 9-14. 
historia literaria de Guatemala y apenas la menciona de pasada. No parece ser fortuito su desdén. Cardoza confronta con dificultad -como también Martínez- la voz del criollo colonial de la élite culta, como queda evidenciado en su conflictiva lectura del propio Landívar. Discurre, en cambio, con gran soltura, comodidad y abierta admiración sobre la obra del conquistador Bernal Díaz del Castillo. Salta entonces, en su análisis de la historia literaria guatemalteca, del siglo XVI al XVIII, dejando a Fuentes y Guzmán y al siglo XVII sin consideración. Contrariamente a lo que hace Severo Martínez al reconocer la palabra canónica de Fuentes como historiador o cronista, Cardoza lo evita como literato. De hecho, su larguísimo "Discurso historial" de tres tomos no está plenamente reconocido en el canon nacional como parte de la historia literaria del país, aunque sí en cambio, en el de la tradición historiográfica. Visto así, el texto de Fuentes, sin el revestimiento de la épica de la conquista de Bernal, ni la perfección formal y el sesgo ideológico de Landívar, que parece anunciar la independencia, no es sino el mundo cerrado y opresivo de la Colonia en pleno declive, es decir, el mundo del criollo colonial y de su lamento de clase. Cardoza quiere una voz popular más directa y rescata esa raíz en Bernal, se identifica con él y con su obra, en la que encuentra más de un paralelismo con la suya. En Landívar, en cambio, echa de menos esa voz. La escritura en latín y la rigurosidad estilísitica del jesuita subraya su elitismo. Sin embargo, tras una lectura difícil y contradictoria, Cardoza retoma de la Rusticatio mexicana si no su propuesta ideológica, sí su temática popular y con ella se queda. Establece el problema en las lecturas que se han hecho del poeta: es la erudición académica la que aleja a Landívar del pueblo:

Quise desempolvarlo, quitarle polilla de bibliotecas y alcanfores. Al ir estudiando a Landívar, pesando lo que nos agrada y lo que nos aleja de él, se afina el tacto, como el del ladrón que espera sentir cuándo cede la cerradura y puede abrirse la caja de caudales ${ }^{21}$.

Nuevamente, un espacio de libros y palabras y un cofre cerrado que aprisiona la verdad a ser develada. Aquí la palabra erudita que encierra la verdad y el lugar que se le asigna padecen los males de lo viejo y en desuso, pero el "estudioso" está ahí. Landívar es el poeta, no del mundo colonial ya exangüe, sino del advenimiento de la nación independiente simbolizada en los juegos y oficios populares. Cardoza "roba", libera, el sentido de las palabras e imágenes del pueblo oculto en las normas eruditas. No abre el cofre luego de un "permiso" concedido, sino cometiendo una transgresión. No encuentra en él claves misteriosas cuyo desciframiento es poder, sino un contenido colorido y brillante que "surge" y se nos muestra de inmediato: chorros de miel de caña y juegos populares de gallos y palo volador. Esta democratización de la palabra y de la vida que retoma Cardoza de estos temas landivarianos dura poco, porque muy pronto reconoce en Landívar al "padre", metáfora por demás ilustrativa del conflicto con la autoridad, con la

${ }^{21}$ Cardoza, Guatemala, las líneas de su mano, 222. 
imposición, con el hecho ineludible de que "las cosas no son como quisiéramos, sino como son".

A su manera, tanto Cardoza como Martínez centran su conflicto con los textos coloniales criollos en la argumentación discursiva de su deslinde del mundo de lo criollo como mundo ideológico de clase, asociado a los antecedentes históricos de los terratenientes guatemaltecos. Para ambos escritores, situados en la segunda mitad del siglo XX, aunque cada uno en un momento particular, la figura del criollo colonial, tanto si este es encomendero, funcionario y cronista como si es un clérigo ilustrado, rememora la imagen de la élite que, con significativas variaciones en el transcurso del tiempo, representa, contradictoriamente, tanto a la clase dominante local, es decir, el "antihéroe" de los proyectos historiográficos y políticos de la izquierda, como al "héroe" intelectual, que expresa en los códigos compartidos de la cultura letrada una identidad si no "nacional" al menos "patriótica", si bien caracterizada por una larga historia de desplazamientos en la estructura del poder. Cardoza y Martínez escriben desde momentos históricos que, en la región y el país, plantean el surgimiento de una alternativa democrática, nacional y popular frente la crisis del modelo oligárquico y de recomposiciones políticas latinoamericanas y mundiales. Siendo ambos intelectuales de los sectores medios radicalizados, encarnan por igual las contradicciones que les son propias. Agotado el recurso de la revolución democrática y nacionalista por la vía electoral, como lo demostró el derrocamiento de dicho proyecto en 1954, ambos se ven obligados a elaborar una reflexión alternativa que contemple aspectos hasta entonces dejados de lado, como la centralidad de la población indígena en cualquier proyecto político popular y la comprensión de las causas históricas de su condición actual y las del conjunto de las persistentes bases de la estructura económico-social e ideológica del país. Atenazados entre su formación intelectual forjada en medio de y en pugna con el mundo oligárquico, su breve experiencia protagónica como parte del sujeto político y radicalizados por la dura experiencia de la derrota y los ulteriores procesos de intervención imperialista, agudización de la pobreza y creciente intolerancia y represión, Cardoza y Martínez representan al intelectual latinoamericano puesto en el trance de encarar el hecho de que no solamente las sociedades en que vivían, sino la literatura y el saber, se habían convertido en un campo de batalla de la posguerra, es decir, de la Guerra Fría ${ }^{22}$.

22 Jean Franco, en su reciente Decadencia y caída de la ciudad letrada. La literatura latinoamericana durante la Guerra Fría (Barcelona: Debate, 2003), inicia su introducción relatando, precisamente, un episodio autobiográfico relativo al golpe de Estado de 1954 en Guatemala y a sus intelectuales, y más adelante afirma que dicha intervención sirvió de preludio al inicio de la Guerra Fría en América Latina, contexto que -según argumenta en su obra- marca significativamente a la literatura y la cultura de la segunda mitad del siglo $\mathrm{XX}$ en la región. 
Vulnerables eran ellos mismos al conservadurismo y represión de los gobiernos de entonces, que realizaron, como lo afirma Jean Franco, el tránsito de la Guerra Fría a la guerra sucia. Vulnerables a la escasez de lectores, a la pobre difusión de la cultura, al autoritarismo, a la complejidad de su condición profesional, en un contexto que -si bien desigualmente- los obliga a ser editores, profesores y políticos, además de escritores, aunque ciertamente recubiertos con el aura del intérprete y del profeta de la historia. Representan también a los sectores medios, cuyo papel en el proceso democratizador de 1944 fue decisivo, pero que fueron desplazados del posterior proyecto que retomara el patrón oligárquico-dependiente. Tal como lo hicieron en su momento Fuentes y Landívar, que reinventa uno la gesta de la Conquista, y prefigura el otro la de la Independencia, buscando así su propio lugar y su propio "mundo" en medio de uno que solo les pertenecía a medias; Cardoza y Martínez, a su manera, buscan también la recuperación del suyo y del lugar que les corresponde en él. Dice Martínez sobre el mundo colonial: "El indio había sido desplazado y el español venía a ver a quien desplazaba". El criollo, que no aparece en la frase, se intuye en el tono resentido de la parte final, en ese oscuro "quien" que era desplazado por el español. Es él quien habla, aunque desde el presente: también el "mundo" de Martínez "desplaza" al indio y también su clase fue desplazada.

Cardoza, por su parte, habla del "mundo" de Landívar: “...colonial, de criollo, jesuita antigueño, de docto humanista que se prende del latín", en una recreación de su compleja relación con él: lejana y cercana, ajena y propia a la vez: "antigueño", "humanista", condiciones compartidas que lo salvan. Un mundo por cierto, del que emerge el esbozo de la patria de la que Cardoza y Landívar son "triplemente paisanos". Una patria para la que bien puede aplicarse la frase que Martínez crea para el criollo Fuentes y Guzmán: "Su mundo le era querido porque era suyo y más hondamente querido porque no era totalmente suyo"

Para reapropiarse del mundo que les ha sido arrebatado, ambos intelectuales elaboran exactamente, como en su tiempo y con similares propósitos lo hicieran Fuentes y Guzmán y Landívar, extensos panoramas y paisajes que se presentan como totalizantes reinterpretaciones históricas y proyectos de futuro para la nación. En la encrucijada de una clase media intelectual formada a caballo entre el mundo oligárquico rural y finquero y el mundo burgués citadino e industrial que conviven cercanamente, aprisionados entre valores ideológicos propios de las jerarquías señoriales, las democracias liberales y las utopías populares, elaboran un discurso que aunque se dirige a este último sector, con el que se identifican ideológicamente, se estructura parcialmente con imaginería de la clase dominante. $\mathrm{Su}$ discurso revolucionario, propio del momento que Guatemala y parte de América Latina vivían a mediados del siglo $\mathrm{XX}$, adquiere tonos y expresiones distintas en cada unos de ellos: en Cardoza, una expresión amorfa entre el romanticismo de los cantos a la zona tórrida del naturalismo, el modernismo de las 
requisitorias patrióticas martianas y el surrealismo vanguardista, con todo y relativismo epistémico y cultural. En Martínez adopta también un sesgo romántico expresado en imágenes paisajísticas y en la arquitectura general de la obra, en la que, sin embargo, domina el impulso del realismo social en la obsesión por la "objetividad" y la pretensión científica de su análisis, en sus temas y conceptos que, con ello, en efecto renuevan radicalmente la historiografía nacional. El conservadurismo en ambos está en el recurso a la épica, en las formas autobiográficas y biográficas, en el vasto recurso a la imaginería colonial, en el referente de la pequeña ciudad provinciana, en el lugar y el tono de la voz de la enunciación, situada muchas veces en "cumbres" y "alturas" que todo lo controlan.

Ni burdamente encomenderos o solamente paternalistas y cursis, Cardoza y Martínez tienen de todo ello, pero tienen mucho más, y con esas rémoras, que son expresión de la sociedad en que sus obras surgieron, lograron plasmar en ellas imágenes y relaciones con el mundo que forman parte indeleble del imaginario colectivo y de la memoria de las generaciones posteriores de guatemaltecos y centroamericanos.

Las dos obras fundacionales de la identidad nacional criolla guatemalteca, la Recordación florida de Fuentes y Guzmán y la Rusticatio mexicana de Rafael Landívar parecen plantear -a la luz de las lecturas y críticas de Martínez y Cardoza, respectivamente- un problema ético-político a ambos intelectuales contemporáneos. Debido quizá a que no existe en la historia de Guatemala un proyecto de nación de raíz popular desde que su posibilidad fue truncada en 1954, el espectro del proyecto criollo que vive en aquellas obras coloniales se proyecta dramáticamente hasta el presente no solamente en la realidad de la alternativa por la que ha transitado el desarrollo capitalista en el país, sino también en los procesos culturales de la sociedad que este logra hegemonizar. De esta manera, la "identidad nacional", anudada históricamente a la ideología señorial del criollo encomendero colonial, plantea a estas obras fundacionales el dilema -por demás propio de su clase y de su tiempo de transición- de proponer rupturas y quiebres problemáticos, como el que enuncia Martínez, con lenguaje e imágenes que conservan anclajes en el pasado, o bien conflictivas continuidades como lo hace Cardoza, enunciadas sin embargo con formas que expresan futurismo y "pasatismo" al mismo tiempo.

La relectura actual de los textos clásicos debe hacerse llevando más allá sus implicaciones y partiendo de imperativos éticos y políticos: por un lado, la revaloración del pensamiento crítico latinoamericano y guatemalteco y de sus prácticas, en dirección a la búsqueda de planteamientos no reductivos que permitan la reapertura de sus debates. Por otro, el desafío al problema ideológico que entraña una práctica de lectura monologal y cerrada de dicho pensamiento crítico, así como la alternativa que se abre con la búsqueda de sus claves en la complejidad de la lengua de los textos en que este encarna. 


\section{Bibliografía}

Anadón, José, ed. Ruptura de la conciencia hispanoamericana. Madrid: Fondo de Cultura Económica, 1993.

Bajtin, Mijaíl. "Las formas del tiempo y el cronotopo en la novela. Ensayos de poética histórica". En Teoría y estética de la novela, trad. Helena Kriúkova y Vicente Cazcarra. Madrid: Altea-Taurus-Alfaguara, 1989.

Cardoza y Aragón, Luis. Guatemala, las líneas de su mano. Guatemala: México: Editorial Universitaria, Universidad de San Carlos, 1997.

. El río, novelas de caballería. México: Fondo de Cultura Económica, 1986.

Carrillo, Ana Lorena. "Crónica, discurso criollo y relato historiográfico en $L a$ patria del criollo de Severo Martínez Peláez". Mesoamérica (Guatemala), 44 (diciembre 2002): 118-133.

Díaz del Castillo, Bernal. Historia verdadera de la conquista de la Nueva España, introd. y notas. Joaquín Ramírez Cabañas. México: Porrúa, 1960.

"Introducción". Crónicas de Indias, Antología, ed. Mercedes Serna. Madrid: Cátedra, 2000.

Echeverría, Maurice. "Cardoza: instantáneas cibernéticas". En Luis Cardoza y Aragón. Centenario 1901-2001. Guatemala: Fondo de Cultura Económica de Guatemala, 2001.

Flores, Ronald. "Cardoza extravagante”. Cultura de Guatemala. Edición homenaje centenario Luis Cardoza y Aragón, Programa Patrimonio Cultural e Identidad NUFU/URL. (Guatemala), 3 (septiembre-diciembre 2001): 211213.

Franco, Jean. Decadencia y caída de la ciudad letrada. La literatura latinoamericana durante la Guerra Fría. Barcelona: Debate, 2003.

Henríquez Ureña, Pedro. Las corrientes literarias en la América hispánica. La Habana: Instituto Cubano del Libro, s. f. 
Irving, Leonard. "Un sabio barroco". En Lectura crítica de la literatura americana. Inventarios, invenciones y revisiones, selección, prólogo y notas Saúl Sosnowski. T. 1: 653-663. Caracas, Venezuela: Biblioteca Ayacucho, 1996.

Landívar, Rafael. Rusticatio mexicana, ed. crítica bilingüe Faustino Chamorro G. Guatemala: Universidad Rafael Landívar, 2001.

Maravall, José Antonio. La cultura del Barroco: análisis de una estructura histórica. Barcelona: Ariel, 1996.

Magris, Claudio. Utopía y desencanto. Historias, esperanzas e ilusiones de la modernidad. Barcelona: Anagrama, 2001.

Martínez Peláez, Severo. La patria del criollo. Guatemala: Editorial Universitaria, Universidad de San Carlos, 1970; reimpresión México: Universidad Autónoma de Puebla, 1981.

Méndez D’Ávila, Lionel. Cardoza y Aragón obra y compromiso (modelo con un paraíso, un infierno y un río). Guatemala: Universidad de San Carlos, 1999.

Méndez de Penedo, Lucrecia. Memorie contracorrente, El río, novelas de caballería de Luis Cardoza y Aragón. Roma: Consiglio Nazionale Delle Ricerche-Bulzoni Editore, 2001.

Molina, Iván. "La patria del criollo, tres décadas después". En La patria del criollo tres décadas después. Óscar Peláez Almengor. Guatemala: Editorial Universitaria, 2000.

Moraña, Mabel. "Para una relectura del Barroco hispanoamericano: problemas críticos e historiográficos". En Lectura crítica de la literatura americana. Inventarios, invenciones y revisiones, Saúl Sosnowski. Caracas, Venezuela: Biblioteca Ayacucho, 1996.

Perus, Francoise. "Aportes de la crítica literaria a la cultura latinoamericana". Latinoamérica. Anuario de Estudios Latinoamericanos (México), 35 (2002): 81-136.

, comp. Historia y literatura. México: Instituto Mora, 1994.

Zimmerman, Marc. Guatemala, voces desde el silencio. Un collage épico. Guatemala: Palo de Hormigo-Óscar de León Palacios, 1993. 
Fecha de recepción: 21 de abril de 2005.

Fecha de aceptación: 23 de agosto de 2005. 